Asian Development Policy Review

$\operatorname{ISSN}(e):$ 2313-8343

$\operatorname{ISSN}(p): 2518-2544$

DOI: 10.18488/journal.107.2020.83.194.213

Vol. 8, No. 3, 194-213.

(C) 2020 AESS Publications. All Rights Reserved.

URL: www.aessweb.com

check for
updates

\title{
TRADE LIBERALIZATION AND ECONOMIC GROWTH: AN
ASSESSMENT OF NIGERIAN EXPERIENCE
}

\author{
Innocent .U. Duru ${ }^{1+}$ \\ Bartholomew .O.N. \\ Okafor $^{2}$ \\ Friday .O. Adikwu ${ }^{3}$ \\ Franklin .C. Njoku ${ }^{4}$
}

\author{
${ }^{\prime}$ Department of Economics, Renaissance University Ugbawka, Enugu State, \\ Nigeria. \\ 'Email:uchechukrouduru1@gmail.com Tel:+234-8065347908 \\ ${ }^{2}$ Department of Economics, Nile University of Nigeria, Nigeria. \\ 'Email:bartholomerv.okafor@yahoo.com Tel:+234-8035884378 \\ ${ }^{3,4}$ Post Graduate Student Department of Economics, University of Abuja, \\ Abuja, Nigeria. \\ 'Email:fovaman@gmail.com Tel:+234-80380578s8 \\ •Email:franklinnjoku21@gmail.com Tel: +234-8039650927
}

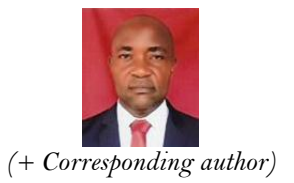

(+ Corresponding author)

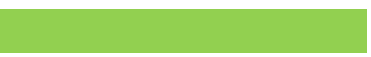

Article History

Received: 22 June 2020 Revised: 29 July 2020

Accepted: 1 September 2020

Published: 17 September 2020

\section{Keywords}

Trade liberalization

Economic growth

Endogenous theory

ARDL model

Toda

Yamamoto

Developing countries

Nigeria.

JEL Classification:

E2; E62; 01 1; 040.

\section{ABSTRACT}

The association between trade liberalization and economic growth in Nigeria was examined in this study from 1981 to 2018. The study used the Autoregressive Distributed Lag Bounds technique to cointegration. The results showed that trade liberalization do not support economic growth in Nigeria. Hence, the genuineness of the extensive trade liberalization campaign in developing countries through the bright idea of international organizations in the late 1980 s and early 1990 s was not validated. Furthermore, the results showed the presence of unidirectional causality from real Gross Domestic Product to trade liberalization in Nigeria. The study, therefore, recommends that policymakers of the government should balance its strategies of trade liberalization as a result of the inability of the economy to absorb the adverse shocks from foreign trade, appropriate fiscal and monetary policies should be deployed by the government for the protection of the economy against foreign influences and the diversification of the structure of export is necessary to ensure that manufactured products are exported more. Also, the Central Bank of Nigeria and policymakers of the government should prescribe sound macroeconomic policies that will ensure price stability to reduce the uncertainties associated with investment in the economy to boost economic growth. The government should also provide incentives to investors and a conducive environment for investment. Moreover, the government should initiate policies of growth for the promotion of trade.

Contribution/ Originality: This study established a fact-based decision making for the realization of a trade-led economic growth and development strategies in Nigeria through the direction of causality between the principal variables. This study has deep evidence of originality; hence, the validity, reliability and uniqueness are not in doubt.

\section{INTRODUCTION}

In the literature of growth and development, the nexus between trade liberalization and economic growth has been a subject of extensive debate among academics, policymakers, researchers in the arena of international trade 
and international development partners particularly in developing countries since the early 1990s. Das (2002) argued that this debate reached new heights due to the success of East Asian countries, third world debt crises and reforms in the East European transition economies. The original claim that trade is a driving force of economic growth is derived from the productivity theory of Adam Smith. The significance of specialization in production and trade was emphasized by the arguments in support of trade as a vehicle of economic growth and the productivity theory (Aditya, 2014). Based on this assertion, it is not surprising that the advantages of liberalization of trade remained contentious and progressively discussed in academic and international policy dialogue.

Also, the new theories of economic growth advanced that through openness to trade, economic growth can be realized by boosting the degree of spillover (Romer, 1990). Trade liberalization through regional, bilateral or multilateral trade agreements creates a competitive environment, permits the diffusion of knowledge and transfer of technology, enhances the competitiveness of export, increases access to the international market, expands the domestic market, creates marketing networks, provides managerial and technical skills, enhances the transformation of technology, results in industrialization, leads to job creation, improves productivity, enhances economic growth, provokes the expansion of the export sector and stimulates the reduction of sectors competing for import.

Besides, traditional theories of trade postulated that trade liberalization reallocates resources in line with comparative advantage, lowers waste, and reduces the price of goods imported in an economic regime that is more transparent, with reduced lobbying activities, and there is more diversification of exports besides rapid expansion (Bittencourt, 2004). Furthermore, there is a consensus among most economists that countries with open economies progress better than those with closed economies in the long-run (Bittencourt, 2004). However, they opined that the short-run effects of trade liberalization can be detrimental to the poor.

In the late 1980 s and early 1990s, virtually all the developing economies in the global economy witnessed trade liberalization and integration, either individually or on the bright idea of multilateral organizations and/or international donor agencies like the World Trade Organization (WTO), World Bank (WB) and the International Monetary Fund (IMF) for the implementation of the Structural Adjustment Programmes (SAP). During this period, outward orientation and trade liberalization were part of the conditionality requirements for giving loans to developing economies. Rodrik (2006) argued that trade liberalization was among the major policy reforms prescribed in the Washington consensus. This had resulted in the proliferation of policies of trade openness and most economies entering into agreements for the integration of trade. The unprecedented integration of the economies of the developing countries to the economies of the rest of the world is expected to spur economic growth.

Trade liberalization could be the propelling force of economic growth and development in the developing economies if properly implemented. Liberalization of external trade motivates long-run economic growth (Chile \& Talukder, 2013; Food and Agriculture Organization, 2005). Numerous countries of the world, especially the developing ones introduced economic openness through the liberalization of their trade and financial sectors. It was through these platforms that countries like China, India and Malaysia, among others opened their economies for foreign direct investments. The extraordinary economic growth and financial growth rates recorded by these countries are traceable to their economic openness (Qazi, 2015). Besides, the part of openness to trade on economic growth as part of a strategy of development was further confirmed by Newfarmer and Sztajerowska (2012) in their contention that developing economies, especially China and other BRICs economies are now main exporters and importers in the world market.

The input of China in the economy of the world accelerated after its economic liberalization in 1992 (Newfarmer \& Sztajerowska, 2012). Several countries of the global economy, without doubt, have felt the impact of the relatively fast development of China. No wonder Dollar and Kraay (2003) declared that economies such as China, India, Malaysia and Mexico that embraced globalization after 1980 experienced a faster rate of economic 
growth than the rich economies whereas at the same time the rate of growth deteriorated for the countries that pursued protectionist trade regime. Furthermore, Krueger (1997) maintained that the fast industrialization and development in the high-growth countries of Hong Kong, Taiwan, South Korea and Singapore tagged the Four East "Asian Tigers", is often used as a reference point of beneficiaries of fruitful trade liberalization strategies since the early 1960 s.

Trade liberalization, a driving force of globalization and a necessary step to realize openness to trade was adopted in Nigeria in 1986 through the SAP of the Breton Woods institutions: WB and the IMF to reverse the negative consequences of past policies of protection embraced in the fifties and sixties. This signaled a departure from an import-substitution strategy to an export-promotion strategy. The protectionist policies were characterized by high import tariffs and prohibitions that discouraged export expansion and diversification. During this period, there was a considerable reduction of barriers to trade and devaluation of the naira. Nigeria joined the WTO in 1995 and committed herself to further reductions of tariff on goods to ensure their free movement.

All the developing countries except for the Asian Tigers, China and India witnessed a gloomy economic growth between the era of 1960 and 1980 (Kebede, 2002). It has, however, remained dismal for most Latin American, Asian and African countries. Before Nigeria adopted the trade liberalization policy in 1986, she experienced poor performance in terms of economic growth for most of the periods. The highest annual Gross Domestic Product (GDP) growth rate after independence was 25\%, 24\% and 14\% for 1970, 1969 and 1971 respectively. Nigeria recorded a negative real GDP growth rate from 1966 to $1968,1975,1978,1981$ to 1984 and 1986. This was majorly as a result of the implementation of the Import Substitution Industrialization (ISI) strategy combined with disinvestment, the economic crisis of the mid-1970s and political instability. Hence, the poor economic performance recorded for the larger part of the pre-liberalization era was caused by the implementation of inappropriate policies.

It was clear that alternative policies were needed to turn the economy around. Nigeria, therefore, embarked on several economic reforms on the platform of a regime of liberalized policy that accompanied SAP in 1986. A negative real GDP growth rate was recorded in 1987. However, positive growth rates were recorded from 1988 to 1990. Despite the reforms implemented to boost economic performance, the growth performance of the postliberalization era provided a dramatic contrast to the ones experienced during the pre-liberalization era. Under Vision 20:2020 economic transformation blueprint, Nigeria was expected to be among the 20 largest economies in the world by the year 2020. Irrespective of these policy initiatives, the average growth rate of real GDP in Nigeria from 1990 to 2018 was only 4.6\% (World Bank World Development Indicators, 2020).

Government dedication towards trade openness is not shared by all, as the country recorded a moderate GDP growth rate since 1986. The recorded GDP growth rate was inadequate compared to enormous government efforts towards trade openness. The average real GDP growth rate from 1990 to 2018 is lower than expected, though commendable. However, it was not unique as expected considering the implementation of trade liberalization policies. The questions that arise from this are: does trade liberalization have any impact on the Nigerian economy? What does the empirical evidence between trade liberalization and economic growth support in Nigeria, causation from trade liberalization to economic growth or causation from economic growth to trade liberalization? The major objective of this study is to explore the nexus between trade liberalization and economic growth in Nigeria. The rest of this paper is arranged as follows: section two would focus on literature review and theoretical framework. The focal point of section three would be the methodology. Section four would concentrate on the presentation of data, analysis and discussions while section five would dwell on conclusion and recommendations. 


\section{LITERATURE REVIEW AND THEORETICAL FRAMEWORK}

\subsection{Empirical Literature}

The link between trade liberalization and economic growth has been investigated by several works of literature with mixed results and submissions. For instance, utilizing the OLS, Echekoba, Okonkwo, and Adigwe (2012) explored the link between trade liberalization and economic growth in Nigeria using data for 1971 to 2012 . The results showed that both imports and exports exerted positive and significant relationships with economic growth in Nigeria. Also, employing annual data from 1989 through 2010, Mercan, Gocer, Bulut, and Dam (2013) used the technique of panel data to examine the impact of trade openness on the economic growth of the fast-emerging economies of Brazil, Russia, India, China and Turkey, tagged BRIC-T. The results revealed that the impact of trade openness on the economic growth of these economies were positive and statistically significant. In another related study, Nduka (2013) used the Ordinary Least Square (OLS) method for the period of 1970 to 2008 to empirically investigate the relationship between trade openness and economic growth in Nigeria. The results of the cointegration test showed the existence of a long-run equilibrium relationship between the variables. The results revealed that openness to trade had a positive and significant relationship with economic growth in Nigeria.

Furthermore, using the Engle-Granger approach to cointegration, Nduka, Chukwu, Ugbor, and Nwakaire (2013) investigated empirically the causal link between openness to trade and economic growth in Nigeria during the pre and post SAP periods of $1970 Q^{1}$ to $1985 Q^{4}$ and 1986-2011 respectively. This study became necessary because the earlier studies accomplished in Nigeria lumped the pre and post SAP periods as one. This may lead to misleading results and thus incoherent policy suggestions. The cointegration results confirmed the existence of a long-run equilibrium relationship between the variables. The results revealed a unidirectional causality running from economic growth to trade openness devoid of feedback (growth-led trade) during the pre-SAP era. On the other hand, there was a bi-directional causality between economic growth and trade openness (growth-led trade and trade-led growth correspondingly) during the post-SAP era. This causality runs from economic growth to trade openness with a response effect. However, the results showed that the impact of economic growth on trade openness was more during the post-SAP era.

Similarly, employing the Classical Linear Regression Model (CLRM) over the period of 1991 to 2013, Kalu, Nwude, and Nnenna (2016) investigated the impact of trade openness on economic growth in Nigeria. The results revealed that export and net export both had positive and significant relationships with economic growth. However, import had a positive and significant link with economic growth. In another related study, Dao (2014) used the technique of panel data and pooled Ordinary Least Square (OLS) regression to examine the nexus between trade liberalization and economic growth for 71 countries panel globally for 1980-2010. The results showed that trade shares had a positive and significant link with economic growth.

Additionally, Manwa (2015) examined the effect of trade liberalization on the economic growth of the five Southern African Customs Union (SACU) countries of Botswana, Namibia, South Africa, Swaziland and Lesotho through the ARDL Bounds testing method to cointegration for the period of 1980 to 2011 . The study utilized fixed-effects panel data estimations as well for testing the strength of empirical findings among the five countries. The results revealed that in the case of Lesotho, Botswana, Swaziland and Namibia, liberalization of trade measured through trade ratios, tariffs, the real effective exchange rate and adjusted trade ratios exerted an insignificant impact on economic growth. However, in the situation of South Africa, trade liberalisation had an impact on economic growth.

Similarly and utilizing the ARDL methodology on time series data from 1971 to 2013, Qazi (2015) examined the effect of financial and trade liberalization on economic growth in Pakistan. Based on the findings of the ARDL model, the long-run association was present in all models. The findings revealed that capital stock, financial liberalization index (banking and stock market) and labour force representing skills were positively linked to 
economic growth. The results further revealed that de facto financial openness index and trade openness had negative impacts on growth.

In another similar study, Dabel (2016) used the Autoregressive Distributed Lag (ARDL) method to cointegration and data from 1986 to 2015 to investigate the relationship between trade openness and economic growth in Ghana. Based on Composite Trade Index (CTI), a new trade openness measure developed by the author, openness to trade had a positive and significant impact on economic growth. Furthermore, the results revealed that real effective exchange rate, labour force, foreign direct investment (FDI) and the capital stock had positive and significant effects on economic growth. However, inflation exerted a negative and significant impact on economic growth. The result of the Granger causality test between trade openness and economic growth showed a unidirectional causality from trade openness to economic growth. Likewise, Keho (2017) used the ARDL Bounds test to cointegration and the Granger causality test of Toda and Yamamoto to investigate the impact of trade openness on economic growth in Cote d'Ivoire for the period of 1965 to 2014. The results showed that trade openness exerted positive impacts on economic growth in both the short-run and the long-run.

Besides, Mangir, Acet, and Baoua (2017) employed the Vector Error Correction Model (VECM) to investigate the link between trade openness and economic growth in Niger from 1970 to 2015. The findings revealed the existence of a bidirectional relationship between trade openness and economic growth in Niger in the short-run. In another related study, Moyo, Nwabisa, and Hlalefang (2017) investigated the long run nexus between trade openness and economic growth in Ghana and Nigeria using the ARDL model from 1980 to 2016. The results revealed the presence of a long-run relationship among the variables for both nations. Furthermore, the findings showed that trade openness exerted a positive and significant effect on economic growth in Ghana. However, openness to trade had a negative and insignificant impact on economic growth in Nigeria.

On the same subject, Moyo and Khobai (2018) investigated the nexus between of trade openness and economic growth for 11 Southern African Development Cooperation (SADC) countries of Botswana, Madagascar, Mauritius, Namibia, Swaziland, Zambia, Lesotho, Malawi, Mozambique, South Africa and Tanzania over the period of 1990 to 2016 using the ARDL Bounds test method and Pooled Mean Group (PMG) model. The findings showed that trade openness exerted a negative impact on economic growth in the long-run. Yakubu and Akanegbu (2018) investigated empirically the association between trade openness and economic growth in Nigeria over the period of 1981 to 2017 using the OLS. The results revealed that the degree of openness exerted a positive and significant impact on economic growth. However, the result of the Granger causality test revealed that there is a unidirectional causality running from real Gross Domestic Product (GDP) to degree of openness.

Also, Elijah and Musa (2019) investigated the dynamic effect of trade openness on Nigeria's economic growth from 1980 - 2016 using the Error Correction Model (ECM). The short-run and long-run results showed that trade openness hurt economic growth in Nigeria. Moreover, Ajayi and Araoye (2019) used the VECM to investigate the impact of trade openness on Nigeria's economic growth for the period of 1970 to 2016. The result of the cointegration test showed the existence of a long-run relationship among the variables. The findings revealed that trade openness had a negative link with economic growth in Nigeria.

Evidence from the literature reviewed showed that some of the studies employed cross-country backgrounds by assessing the results of trade liberalization between developing and developed economies or within a designated group of developing countries (Barro \& Sala-i-Martin, 1997; Dollar \& Kraay, 2003; Dollar, 1992; Edwards, 1998; Greenaway, Morgan, \& Wright, 2002; Harrison, 1996; Read \& Parton, 2009; Sachs \& Warner, 1995; Vamvakidis, 2002). The results of the link between trade liberalization and economic growth were mixed. Most studies (Aboubacar, Xu, \& Ousseini, 2014; Ajayi \& Araoye, 2019; Ali \& Abdullah, 2015; Ben-David, 1993; Constant, 2010; Dabel, 2016; Dao, 2014; Dollar, 1992; Edwards, 1998; Elijah \& Musa, 2019; Falvey, Foster, \& Greenaway, 2012; Frankel \& Romer, 1999; Greenaway et al., 2002; Harrison, 1996; Kalu et al., 2016; Keho, 2017; Kneller, Morgan, \& Kanchanahatakij, 2008; Mercan et al., 2013; Michaely, Choksi, \& Papageorgiou, 1991; Moyo et al., 2017; Nduka, 
2013; Nduka et al., 2013; Olufemi, 2004; Ramzan \& Kiani, 2012; Sachs \& Warner, 1995; Sakyi, 2011; Sala-i-Martin, 1997; Salvatore \& Hatcher, 1991; Savvides, 1995; Vamvakidis, 1999; Wang \& Yao, 2003; Winters, 2004; Yakubu \& Akanegbu, 2018) concluded that trade liberalization exerts a positive impact on economic growth. Other studies were of the view that trade liberalization affects economic growth negatively (Adhikary, 2011; Bibi, 2014; Moyo \& Khobai, 2018; Musila \& Yiheyis, 2015; Olasode, Raji, Adedoyin, \& Ademola, 2015; Qazi, 2015; Rigobon \& Rodrik, 2005; Rodrik, Subramanian, \& Trebbi, 2002). Furthermore, some studies have found that trade liberalization results in economic growth under certain conditions (Dollar \& Kraay, 2003; Dufrenot, Mignon, \& Tsangarides, 2010; Krugman, 1990; Levine \& Renelt, 1992; North, 1990).

The endogenous growth theory dominated in terms of the framework of modelling used by scholars. The various models hypothesized that the benefits of trade expand economic growth. However, contrary to this proposition, the empirical literature on trade liberalization and economic growth had not presented positive results. Several factors such as insufficient time frames and samples, usage of multiple instruments of measurement, differences of production functions within countries and use of diverse cross-section, time series, panel data, partial equilibrium and Computable General Equilibrium (CGE) models have been responsible for this disagreement (Manwa, 2015). Another factor is the trade openness measure adopted for the study. The modelling of trade liberalization-growth nexus had centred on time series and panel data modelling. Time series modelling was used for country-specific studies whereas cross-country studies employed panel data (Kneller et al., 2008). Previous time series models suffered from shortcoming such as employment of statistical procedures that struggled to establish causality. Numerous trade liberalization measures were utilized in the literature. This study used the commonly adopted indicator of shares of trade in the form of the ratio of the sum of exports and imports divided by GDP as a measure of trade openness. However, the empirical evidence had remained contentious.

The literature on the impact of trade liberalization on economic growth in Nigeria is few. There were some efforts deploying diverse methodologies to investigate the relationship between trade liberalization and economic growth in Nigeria (Ajayi \& Araoye, 2019; Echekoba et al., 2012; Elijah \& Musa, 2019; Kalu et al., 2016; Nduka, 2013; Nduka et al., 2013; Yakubu \& Akanegbu, 2018). The methodologies used by Echekoba et al. (2012); Nduka (2013); Kalu et al. (2016) and Yakubu and Akanegbu (2018) were faulty. They utilized OLS for examining the nexus between trade openness and economic growth. In our estimations, economic theory affirms that trade liberalization is a major factor of economic growth. Usually, as trade liberalization increases, economic growth also increases. Hence, trade liberalization causes economic growth.

In the same vein, economic theory also asserts that fast economic growth motivates trade liberalization. The high GDP growth rate is a positive factor of trade liberalization and trade liberalization could affect economic growth positively. This point of view suggests the likelihood of a bidirectional link between trade liberalization and economic growth. Under this situation, the application of single-equation methodologies like the OLS would result in biased and inconsistent estimates. Still, the presence of endogeneity cannot be accounted for by this form of a model. Hence, the estimates of the studies that utilized OLS would be biased and inconsistent. Again, there was no standard measure for trade openness in the work of Echekoba et al. (2012). Also, Kalu et al. (2016) employed a wrong measure for trade openness. They measured trade openness as net export defined as an export minus import. However, rigorous works on the association between trade liberalization and economic growth are sparse. This makes it complicated for policymakers to develop legislation based on academic research as a result of the absence of agreement on the association between trade liberalization and economic growth.

Again, the majority of the previous studies in Nigeria utilized the bivariate Granger causality test to establish the path of causation between trade liberalization and economic growth. At times, Granger causality or noncausality is hard to employ to ascertain exogeneity. Hence, it is a necessary but not sufficient condition for true causality or robust exogeneity. Despite all these studies with mixed outcomes, the argument, among economists, on the relationships and causality between trade openness and economic growth is still open. Besides, some scholars 
(see Rodriguez and Rodrik (2001) for instance) contended that the deliberation on the trade openness-growth causality is still open because most of the supporting works on this empirical proof suffer from a minimum of two serious criticisms that often question their results. The first flaw has to do with the measurement of trade openness. The second one stems from retained assessment techniques.

Thus, this study utilized the ARDL technique to account for the existence of endogeneity. Also, it permits the control of country-specific variables, time-invariant variables, and the analysis of the long-run nexus between trade liberalization and economic growth Manwa (2015). In recognition of the gaps created in earlier studies through lack of agreement in terms of results, sparse nature of studies, weaknesses of some of the approaches employed and contradictions in the estimation, this study intends to fill these gaps by investigating the effect of trade Liberalization on economic growth in Nigeria from 1981 to 2018. The time frame was based on the premise that the Nigerian economy assumed a diverse outlook beginning in 1986, which marked the kick-off of trade liberalization. Hence, this study departs from most of the earlier studies in terms of scope and methodology. It employed the Toda and Yamamoto Multivariate Causality Test to ascertain the course of causation between trade liberalization and economic growth against the bivariate Granger causality test employed by the majority of the previous studies in Nigeria.

\subsection{Theoretical Framework}

Three main models explain the benefits of trade liberalization to countries (Thindwa \& Seshamani, 2014). These are the theory of comparative advantage by David Ricardo, Heckscher-Ohlin (H-O) theory and the new growth theory or the endogenous growth theory. The theory largely used by scholars for investigating the nexus between trade liberalization and economic growth is the new growth theory or the endogenous growth theory of Romer (1986); Lucas (1988); Romer (1990); Grosman and Helpman (1991) and Barro and Sala-i-Martin (1997). In light of the above, this paper will be hinged on the new growth theory or the endogenous growth theory.

David Ricardo expounded the classical theory of comparative advantage in 1817. The model suggested that specialization by each country in the production of a commodity in the area of their comparative advantage leads to the attainment of gains from trade (Salvatore, 2007). From the perspective of the comparative advantage model, effective use of the resources of an economy is generated through trade by allowing the imports of goods and services that would have been produced at a higher cost at home. The developing countries would serve as the best illustration for this based on the high cost of import capital and intermediate goods necessary for economic growth when fashioned locally. This model emphasized on trade as the artery for the attainment of static efficiency in production and international competitiveness that result in economic growth.

Gains from trade are either static or dynamic. Static gains from trade emanate from the point that nations have various factor endowments and thus, the opportunity cost of production varies between nations. On the other hand, dynamic gains from trade emanate from the increased engagement of resources in production (Thindwa \& Seshamani, 2014). Access to the market is improved through trade liberalization. These gains from trade could be reaped by Nigeria through trade liberalization as a result of improved access to the global markets. Economic growth will be boosted through the foreign exchange gotten from trade. Attainment of new knowledge and technology and increased labour productivity are channels through which dynamic gains could manifest (Thindwa \& Seshamani, 2014).

The Heckscher-Ohlin (H-O) theory was established through the platform of David Ricardo's theory of comparative advantage (Thindwa \& Seshamani, 2014). It supports the idea that countries can participate in international trade by exporting commodities based on their comparative advantage. Furthermore, it sees comparative advantage from the perspective of factor abundance and intensity in a particular country. Therefore, a nation has a comparative advantage if a particular resource is in abundance in that nation and if that resource has a high ratio in production (factor intensity) comparative to others. Salvatore (2007) argued that any resource that 
shows these features, the country that utilizes it for the production of a commodity has a comparative advantage. When countries specialize in production and trade, a high standard of living is generated for the countries concerned. Nigeria is a labour-abundant country with rich deposits of natural resources such as crude oil and several solid minerals. Concerning this, formal and informal employments have been created in the trade and investment sector of the economy. Income is expected to result in the multiplier process.

Because the new growth theory endogenises change in technology, the impact of changes in policy on economic growth can be explained through it. In the submissions of this model, economic growth results through innovation, knowledge and human capital investment considered as internal factors in an economy. Economies of scale stem from the development of human capital besides investment in research and development (R\&D) (Thindwa \& Seshamani, 2014). Besides, the reduction in price distortions ensures the effective allocation of domestic resources across different sectors of the economy. Once advanced technology is deployed in the production process, externalities are generated leading to economic development (Howitt, 1998).

The resources in the Nigerian economy are employed for the promotion of the export sector. The exporters in the domestic economy have increased their horizon in terms of value addition to the final product exported through various initiatives for building capacity that resulted from R\&D. The knowledge base of most farmers dedicated to export has increased through the activities of the extension workers from the Federal Ministry of Agriculture and Rural Development. This had resulted in the adoption of modern farming methods. This is in line with the submissions of the endogenous growth theory that learning-by-doing effects, access to technologies and better management practices lead to more efficiency gains (see (Hart, 1983; Krugman, 1987; Lucas, 1988; Romer, 1990)). Entrepreneurial activity may be stimulated by the trade liberalization policies to the benefit of the Nigerian economy. Furthermore, having adopted and implemented trade liberalization policies, based on theoretical rationality, it is expected that trade liberalization should spur economic growth through the growth of export in Nigeria.

\section{METHODOLOGY}

\subsection{Data}

We employed annual time series data from 1981 to 2018 for the study (see Table 7 in the appendices). All the data required were derived from the WB World Development Indicators (WDI) database. Economic theory, extant literature and data availability informed the choice of the variables. Furthermore, the dependent variable was measured through the Gross Domestic Product (GDP) per capita stated in constant 2010 US\$ and logarithm form. The openness to trade was measured through the sum of exports and imports stated as a ratio of GDP $(\mathrm{X}+\mathrm{M} / \mathrm{GDP})$ and it was used to measure trade liberalization. It is one of the commonly used trade openness indicators in the literature. The gross fixed capital formation was used as a proxy for capital stock. The remaining independent variables were the inflation rate and the general Government final consumption expenditure. The variable name, definition, source and expected sign are shown in Table 1.

Table-1. Variable name, definitions, measures, sources and expected signs

\begin{tabular}{|c|c|c|c|}
\hline Variable Name & Definition and/or proxy & Source & Expected Sign \\
\hline \multicolumn{4}{|l|}{ Dependent Variable } \\
\hline $\begin{array}{l}\text { GDP per Capita growth rate } \\
\text { (RGDPPC) }\end{array}$ & $\begin{array}{l}\text { Gross Domestic Product (GDP) per capita } \\
\text { (Constant } 2010 \mathrm{US} \$ \text { ) in logarithm form }\end{array}$ & WB, WDI & Dependent Variabl \\
\hline \multicolumn{4}{|l|}{ Independent Variables } \\
\hline Trade openness (TOPEN) & Sum of exports and imports divided by GDP & WB, WDI & Positive \\
\hline $\begin{array}{l}\text { Gross fixed capital formation } \\
(\mathrm{GFCF})\end{array}$ & Gross fixed capital formation (\% of GDP) & WB, WDI & Positive \\
\hline Inflation rate (INFL) & Inflation rate measured by the consumer price index & WB, WDI & Negative \\
\hline $\begin{array}{l}\text { General government final } \\
\text { consumption expenditure } \\
(\text { GOVFCEXP) }\end{array}$ & $\begin{array}{l}\text { General Government final consumption expenditure } \\
(\% \text { of GDP }) \text {. }\end{array}$ & WB, WDI & Negative \\
\hline
\end{tabular}




\subsection{Model Specification}

The endogenous growth theory provided the theoretical underpinning for this model specification. Based on this model, technology was suggested to be a critical factor in economic growth. The conventional inputs of economic growth and technology were specified by the analytical framework for investigating the nexus between trade liberalization and economic growth in the literature of economic growth. Therefore, following Chartas (2012) the Cobb-Douglas production function in Equation 1 formed the foundation of the analytical framework for estimating the relationship between trade liberalization and economic growth.

$$
Y=A K^{a} L^{b}
$$

Where:

Y denotes the level of output (a proxy for economic growth).

A represents the exogenous state of technology or the efficiency of production.

$\mathrm{K}$ signifies the amount of capital.

L symbolizes labour.

The model showed that output is determined by the productivity parameter and its inputs of labour and capital. The model used for this study was based on Manwa (2015) with some modifications. Supposing that the production function takes a linear form, the general form of the model estimated in this paper has the following form as depicted in Equation 2.

$$
R G D P P C_{t}=\alpha_{t}+\beta X_{t}+\mu_{t}
$$

Where:

RGDPPC signifies real GDP per capita growth rate.

$\mathrm{X}$ is a set of independent variables that influence Real Gross Domestic Product (RGDP).

t captures the time dimension of 1981-2018.

$\mu_{\mathrm{t}}$ is the error term.

Based on the intuitions given by this author concerning the anticipated link between trade liberalization and some causal variables, a general empirical model between trade liberalization and economic growth in Nigeria can be put as:

$$
\log \left(R G D P P C_{t}\right)=\propto_{0}+\beta_{1} \text { TOPEN }{ }_{t}+\beta_{2} G F C F+\beta_{a} I N F L+\beta_{4} \text { GOVFCEXP }+\mu_{t}
$$

\section{Where:}

$\propto_{0}, \beta_{1}, \beta_{2}, \beta_{\mathrm{a}}$ and $\beta_{4}=$ Parameters in the model
$R G D P P C_{t}=$ Log of real GDP per capita at time $t$
TOPEN
R $=$ Trade openness measured as $\left(X+\frac{M}{G D P}\right)$ at time $t$
$G F C F_{t}=$ Gross fixed capital formation at time $t$
$I N F L_{t}=$ Inflation rate measured by the consumer price index at time $t$ 


\section{$\mu_{t}=$ Error term}

The RGDPPC was logged as a result of highly skewed values. The logarithmic transformation was meant to transform it into a dataset that is more normalized to avoid the problem of heteroscedasticity. The rest of the regressors were not stated in logarithms since they did not depict highly skewed values. The variables were each indexed by country (i) and period $(\mathrm{t}$ ). Before the estimation of the equation of economic growth, the time-series properties of the data were checked through the Augmented Dickey-Fuller (ADF) and Phillips-Perron (PP) unit root tests. Also, the goodness of fit and model adequacy of our specification was confirmed through the diagnostic and stability tests. The ARDL Bounds test technique to cointegration recommended first by Pesaran and Shin (1999) and upheld by Pesaran, Shin, and Smith (2001) was used for estimation of the growth equations. This method reveals the short-run dynamics apart from the estimated long-run coefficients. Version 9 of the E-views econometric software was employed for the computation of the ARDL statistical process.

Equation 3 is formulated into the ARDL model as follows:

\section{$\log \left(R G D P P C_{t}\right)$}

$$
\begin{aligned}
& =\propto_{0}+\sum_{i=1}^{\rho} \propto_{1, i} \Delta \log \left(\operatorname{RGDPPC}_{t-i}\right)+\sum_{i=1}^{\rho} \propto_{2, i} \Delta \text { TOPEN }_{t-i} \\
& +\sum_{i=1}^{\rho} \propto_{3} \Delta G F C F_{t-i}+\sum_{i=1}^{\rho} \propto_{4} \Delta I N F L_{t-i}+\sum_{i=1}^{\rho} \propto_{5} \Delta G O V F C E X P_{t-i} \\
& +\beta_{1} \log \left(\text { RGDPPC }_{t-i}\right)+\beta_{2} \text { TOPEN }_{t-i}+\beta_{3} G F C F_{t-i}+\beta_{4} I N F L_{t-i} \\
& +\beta_{5} G O V F C E X P_{t-i} \\
& +\mu_{t}
\end{aligned}
$$

Where p signifies the lag length, $\Delta$ symbolizes the difference operator, $\alpha_{0}$ denotes the drift, $\mu_{\mathrm{t}}$ represents the disturbance term, $\alpha_{1}, \alpha_{2}, \alpha_{3}, \alpha_{4}, \alpha_{5}$ are parameters of short-run dynamics whereas the coefficients of the long-run relationship are $\beta_{1}, \beta_{2}, \beta_{3}, \beta_{4}, \beta_{5}$.

Under the ARDL bounds testing method, the occurrence of a level relationship between RGDPPC and the causal factors would be investigated. The null and alternative hypotheses can be tested with the F-test to ascertain the existence of cointegration. In Equation 4, the parameters that would be tested under the null and alternative hypotheses of absence and presence of long-run relationships between economic growth and the causal factors are specified as:

$H_{0}: \beta_{1}=\beta_{2}=\beta_{3}=\beta_{4}=\beta_{5}=0$

against:

$$
H_{1}: \beta_{1} \neq \beta_{2} \neq \beta_{3} \neq \beta_{4} \neq \beta_{5} \neq 0
$$

If the $\mathrm{F}$-statistic falls below the critical values lower bounds, the null hypothesis would be sustained and absence of a long-run relationship would be concluded. However, if the F-statistic outstrips the critical values upper bounds, the null hypothesis would be rejected and the presence of cointegration would be concluded among the variables. However, the test is inconclusive if the $\mathrm{F}$-statistic falls between the lower and upper bounds. 
The process would terminate if there was no cointegration among the variables. However, if cointegration exists among the variables, we would evaluate the short-run and long-run coefficients. The OLS can be employed to calculate the long-run elasticities using the platform of Equation 5.

\section{$\log \left(R G D P P C_{t}\right)$}

$$
\begin{aligned}
& =\propto_{0}+\sum_{i=1}^{\rho} \propto_{1, i} \Delta \log \left(\operatorname{RGDPPC}_{t-i}\right)+\sum_{i=1}^{\rho} \propto_{2, i} \Delta \operatorname{TOPEN}_{t-i} \\
& +\sum_{i=1}^{\rho} \propto_{3} \Delta G F C F_{t-i}+\sum_{i=1}^{\rho} \propto_{4} \Delta I N F L_{t-i}+\sum_{i=1}^{\rho} \propto_{5} \Delta G O V F C E X P_{t-i} \\
& +\mu_{t}
\end{aligned}
$$

The final step would be the estimation of an error correction model. Under this situation, an error correction model connected with estimates of the long-run was used to establish causality as depicted in Equation 6.

$\triangle \log \left(R G D P P C_{t}\right)$

$$
\begin{aligned}
& =\propto_{0}+\sum_{i=1}^{\rho} \propto_{1, i} \Delta \log \left(R G D P P C_{t-i}\right)+\sum_{i=1}^{\rho} \propto_{2, i} \Delta T O P E N_{t-i}+\sum_{i=1}^{\rho} \propto_{a} \Delta G F C F_{t-i}+\sum_{i=1}^{\rho} \propto_{4} \Delta I N F L_{t-i} \\
& +\sum_{i=1}^{\rho} \propto_{5} \Delta G O V F C E X P_{t-i}+\pi e c m_{t-i}+\mu_{t}(6)
\end{aligned}
$$

Where $\alpha_{1}, \alpha_{2}, \alpha_{3}, \alpha_{4}, \alpha_{5}$ are the short-run dynamics coefficients, $\pi$ denotes the speed of adjustment and ecm $e_{t-1}$ symbolizes the error correction term. The speed of adjustment is anticipated to be negative and significant to verify the existence of cointegration among the variables. Manwa (2015) stated, "causality is determined through the significance of the coefficient of the lagged error correction term and joint significance of the coefficients of the

\begin{tabular}{|c|c|c|c|c|c|c|}
\hline \multirow[t]{2}{*}{ Variable } & \multicolumn{3}{|c|}{ Augmented Dickey-Fuller (ADF) } & \multicolumn{3}{|c|}{ Phillips-Perron (PP) } \\
\hline & Level & $\begin{array}{c}\text { First } \\
\text { Difference }\end{array}$ & $\mathbf{I}(\mathbf{d})$ & Level & $\begin{array}{c}\text { First } \\
\text { Difference }\end{array}$ & $\mathbf{I}(\mathbf{d})$ \\
\hline $\log ($ RGDPPC $)$ & -0.8814 & $-3.8259^{* * *} *$ & $\mathrm{I}(1)$ & -0.2645 & $-3.8259 * * *$ & $\mathrm{I}(1)$ \\
\hline TOPEN & -2.2771 & $-7.3465^{* * * *}$ & $\mathrm{I}(1)$ & -2.2771 & $-7.8886^{* * * *}$ & $\mathrm{I}(1)$ \\
\hline GFCF & $-3.4206^{* *}$ & - & $\mathrm{I}(\mathrm{O})$ & $-3.3802^{* *}$ & - & $\mathrm{I}(\mathrm{O})$ \\
\hline INFL & -2.8865 & $-5.5869 * * *$ & $\mathrm{I}(1)$ & -2.7575 & $-9.4274 * * *$ & $\mathrm{I}(1)$ \\
\hline GOVFCEXP & -1.1247 & $-5.5556^{* * * *}$ & $\mathrm{I}(1)$ & -1.3051 & $-5.6168 * * *$ & $\mathrm{I}(1)$ \\
\hline
\end{tabular}
lagged differences of the right-hand side variables using the F-test” (pp. 135-136).

\section{PRESENTATION OF DATA, ANALYSIS AND DISCUSSION OF RESULTS}

4.1. Augmented Dickey-Fuller (ADF) and Phillips-Perron (PP) Unit Root Tests Results on Series

Table-2. ADF and PP unit root tests results.

The results of the unit root tests are shown in Table 2. The findings showed that the variables were either $\mathrm{I}(\mathrm{O})$ or I(1). The variables ( $\log (\mathrm{RGDPPC})$, TOPEN, INFL, and GOVFCEXP) were integrated at the first difference $\mathrm{I}(1)$ while GFCF was integrated at the level $\mathrm{I}(0)$. The ADF results were validated through the PP unit root test. The results depicted that the findings of the PP unit root test are a corroboration of those realized utilizing the ADF. The unit root test results of $\mathrm{I}(1)$ and $\mathrm{I}(\mathrm{O})$ exhibited by our variables justified the usage of the ARDL technique. 
Table-3. Results of Diagnostic Tests.

\begin{tabular}{l|c|c|l|c}
\hline \multicolumn{1}{c|}{ Test } & Test Statistic & P-value & Null Hypothesis & Conclusion \\
\hline $\begin{array}{l}\text { Breusch-Godfrey Serial } \\
\text { Correlation LM Test }\end{array}$ & 1.081886 & 0.3600 & $\begin{array}{l}\mathrm{H}_{\mathrm{o}} \text { : No serial } \\
\text { correlation }\end{array}$ & Cannot reject $\mathrm{H}_{\mathrm{o}}$ \\
\hline Ramsey RESET test & 1.521075 & 0.1447 & $\mathrm{H}_{\mathrm{o}}$ : Correctly specified & Cannot reject $\mathrm{H}_{\mathrm{o}}$ \\
\hline $\begin{array}{l}\text { Jarque-Bera normality test } \\
\text { Heteroskedasticity Test: } \\
\text { ARCH }\end{array}$ & 1.084890 & 0.5813 & $\begin{array}{l}\mathrm{H}_{\mathrm{o}} \text { : Normal } \\
\text { distribution }\end{array}$ & Cannot reject $\mathrm{H}_{\mathrm{o}}$ \\
\hline
\end{tabular}

The results of the diagnostic tests were shown in Table 3. The serial correlation of the residuals was tested through the Breuch Godfrey test or Lagrange Multiplier (LM). The null hypothesis of no serial correlation was sustained because the probability value of 0.3600 was more than the 5 per cent significance level. Thus, there was no serial correlation in our model. The probability value of 0.1447 against the Ramsey Regression Equation Specification Error Test (RESET) test was greater than the proposed 5 per cent level of significance. Thus, the null hypothesis that the model was correctly specified was sustained. Thus, there was no possibility of the model not being specified correctly which may result in the omission of certain variables. Again, the model has no wrong functional form. Besides, there was no relationship between the explanatory variables and the residuals. Under the Jarque-Bera normality test, a probability value of 0.5813 was larger than the proposed level of significance. This suggests that the errors were normally distributed due to the upholding of the null hypothesis of normal distribution. Alternatively, because the Jarque-Bera value of 1.0849 was less than 5.99, the null hypothesis of normal distribution was upheld. The result of the ARCH test showed that there was no heteroscedasticity in our model. This is because we accepted the null hypothesis of homoscedasticity. A probability value of 0.2485 showed that the errors were homoscedastic and independent of the explanatory variables. Hence, the model has a good fit and is adequate for analysis.

\subsection{Bounds Test Results for Cointegration}

Table-4. Bounds tests for the existence of cointegration

\begin{tabular}{c|c|c|c|c|c}
\hline Test Statistic & Value & Lag & $\begin{array}{c}\text { Significance } \\
\text { Level }\end{array}$ & \multicolumn{2}{|c}{$\begin{array}{c}\text { Bound Critical Values* } \\
\text { Lower Bound Upper Bound }\end{array}$} \\
\hline$F$-statistic & 3.373319 & 2 & & $\mathrm{I}(0)$ & $\mathrm{I}(1)$ \\
\hline & & & $1 \%$ & 4.40 & 5.72 \\
\hline & & & $5 \%$ & 3.47 & 4.57 \\
\hline
\end{tabular}

Table 4 revealed the Bounds tests result for the presence of cointegration. Depending on these results, the calculated $F$-statistic for the combined test of the parameters $\beta_{1}, \beta_{2}, \beta_{3}, \beta_{4}$ and $\beta_{5}$ was 3.373319. The critical value bounds were 3.47 and 4.57 at the 95 per cent significance level. In the case of our model, the F-statistic got (3.373319) falls between the lower bound $\mathrm{I}(0)$ and upper bound $\mathrm{I}(1)$ of the critical value band computed by Narayan (2004) and Pesaran et al. (2001). Thus, the reason for considering long-run and short-run models. 
Table-5. Estimated long-run coefficients results

\begin{tabular}{c|c|c|c|c}
\hline Dependent Variable: $\log (\mathrm{RGDPPC})$ \\
\hline Variable & Coefficient & Std. Error & t-Statistic & Prob. \\
\hline C & 10.080846 & 5.002903 & $2.014999^{*}$ & 0.0575 \\
\hline TOPEN & -0.002072 & 0.008624 & 0.240319 & 0.8125 \\
\hline GFCF & -0.045010 & 0.076814 & -0.585956 & 0.5645 \\
\hline INFL & -0.008762 & 0.015188 & -0.576921 & 0.8215 \\
\hline GOVFCEXP & 0.011048 & 0.048325 & 0.228625 & 0.1245 \\
\hline Note: * denote significance at $10 \%$.
\end{tabular}

Note: * denote significance at $10 \%$

Table 5 confers the findings of the long-run estimates of the trade liberalization-growth nexus. The long-run results revealed that trade liberalization exerted a negative impact on economic growth contrary to expectation. This suggests that a unit increase in trade liberalization would result in 0.002 per cent decline in economic growth. This further suggests that trade liberalization does not stimulate economic growth in Nigeria. The plausible reason for this result is Nigeria's inability to export products that are diversified critical for trade liberalization to exert the desired impact on economic growth. Alternatively, the plausible reason for this result is the dominance of crude oil export in Nigeria's foreign trade whose price is susceptible to the fluctuations of international oil price. Again, the production quota is determined by the Organization of the Petroleum Exporting Countries (OPEC). Also, in the view of Romer (1990) it means that the generated technology through trade liberalization cannot be effectively utilized by the local resources of the nation. This finding aligns with the submissions of Rodrik et al. (2002); Rigobon and Rodrik (2005); Adhikary (2011); Bibi (2014); Qazi (2015); Olasode et al. (2015); Musila and Yiheyis (2015); Moyo et al. (2017); Moyo and Khobai (2018) and Tyopev (2019). However, this finding is against theoretical expectation proposed by the classical scholars regarding the part of the trade-in the economy. Also, It diverges from the theoretical declaration of Lucas (1988) and Romer (1990). Furthermore, it is contrary to the submissions of other empirical studies such as Edwards (1998); Sachs and Warner (1995); Nduka (2013); Dollar (1992); Sala-iMartin (1997); Harrison (1996); Vamvakidis (1999); Frankel and Romer (1999); Greenaway et al. (2002); Olufemi (2004); Winters (2004); Kneller et al. (2008); Sakyi (2011); Falvey et al. (2012); Nduka et al. (2013); Dao (2014); Ali and Abdullah (2015); Dabel (2016); Kalu et al. (2016); Keho (2017); Yakubu and Akanegbu (2018); Elijah and Musa (2019) and Ajayi and Araoye (2019).

Also, the gross fixed capital formation had a negative and insignificant impact on economic growth against expectation. This means that a unit increase in gross fixed capital formation would decrease economic growth by 0.05 per cent. It further shows that investment does not support growth in Nigeria. Hence, investment does not represent the potential for the expansion of the Nigerian economy. This may be as a result of the hostile investment climate in Nigeria. This result is not in line with present literature on economic growth that stresses capital deepening. This result is against the submissions of Duru and Ehidiamhen (2018). The effect of macroeconomic stability measured by inflation on economic growth was negative in line with a prior expectation. This means that a unit increase in inflation would reduce economic growth by 0.009 per cent. This further shows that the inflation rate sustained in Nigeria during the period of the sample was high and detrimental to consumption and production resulting in a reduction in economic growth. Fluctuating and high rates of inflation intensify the uncertainty of investments through the reduced return. As the uncertainty increases, economic tension increases internally, domestic and foreign investments are dampened which affects economic growth negatively.

Since capital investment rate is reduced as a result of the increased cost of credit caused by high inflation rates, economic growth would be affected negatively. This result conforms to the submissions of Anyanwu, Siyan, and Duru (2009); Dabel (2016); Moyo et al. (2017); Moyo and Khobai (2018) but contravenes that of Bekele (2017). Furthermore, general government final consumption expenditure exerted a positive and insignificant impact on 
economic growth. This suggests that a unit increase in government final consumption expenditure would increase economic growth by 0.01 per cent. The non-significance of this variable has to do with the government operational quality that varies from time to time. Furthermore, the positive relationship with economic growth implies that the quality of government operations in terms of public infrastructural investment projects in the areas of hospitals, roads and schools is yielding the desired results and affecting growth positively. The non-significance of the government final consumption expenditure variable may not be unconnected with some unproductive spending of government that tends to raise its debts, hence affecting its growth potential. This finding, however, contradicts the submissions of Edwards (1992); Sachs and Warner (1995); Barro (1996); Harrison (1996); Vamvakidis (2002) and Dao (2014) for 71 countries panel worldwide.

\subsection{Short-run Dynamic Model Results}

Table-6. Estimated short-run error correction model results.

\begin{tabular}{|c|c|c|c|c|}
\hline \multicolumn{5}{|c|}{ Dependent Variable: $\log ($ RGDPPC) } \\
\hline Variable & Coefficient & Std. Error & t-Statistic & Prob. \\
\hline$\Delta \mathrm{LOG}(\mathrm{RGDPPC}(-1))$ & 0.325683 & 0.245961 & 1.324126 & 0.2004 \\
\hline$\Delta($ TOPEN $)$ & -0.000201 & 0.000880 & -0.228823 & 0.8213 \\
\hline$\Delta(\operatorname{TOPEN}(-1))$ & 0.001071 & 0.000815 & 1.312795 & 0.2041 \\
\hline$\Delta(\mathrm{GFCF})$ & -0.005581 & 0.001763 & $-3.165743 * * *$ & 0.0049 \\
\hline$\Delta(\mathrm{GFCF}(-1))$ & 0.001595 & 0.001276 & 1.250484 & 0.2256 \\
\hline$\Delta(\mathrm{INFL})$ & -0.001048 & 0.000456 & $-2.297367^{* *}$ & 0.0325 \\
\hline$\Delta(\mathrm{INFL}(-1))$ & 0.000764 & 0.000444 & 1.720021 & 0.1009 \\
\hline$\Delta($ GOVFCEXP $)$ & -0.002145 & 0.005845 & -0.367048 & 0.7174 \\
\hline$\Delta($ GOVFCEXP $(-1))$ & -0.001789 & 0.006117 & -0.292486 & 0.7729 \\
\hline $\mathrm{ECM}_{\mathrm{t}-1}$ & -0.098139 & 0.129395 & -0.758443 & 0.4570 \\
\hline \multicolumn{5}{|c|}{$\begin{array}{l}\mathrm{ECM}=\mathrm{LOG}(\mathrm{RGDPPC})+0.0021 * \mathrm{TOPEN}+0.0450 * \mathrm{GFCF}+0.0088^{*} \mathrm{INFL}-0.0110 * \mathrm{GOVFCEXP}- \\
10.0808 * \mathrm{C}+0.0433 * \mathrm{D}\end{array}$} \\
\hline
\end{tabular}

Table 6 confers the short-run dynamic estimates of the link between trade liberalization and economic growth. The results of the short-run dynamics to a large extent corroborate the findings of the long-run results. Change in the log of real GDP per capita of the previous year had a positive and insignificant impact on economic growth. Also, change in trade liberalization exerted a negative and insignificant impact on economic growth. This means that trade liberalization does not contribute to economic growth in the short-run. This result is in line with the submissions of Tyopev (2019) but contradicts those of Moyo et al. (2017). This finding is consistent with the longrun results. However, trade liberalization of the previous one year had a positive and insignificant impact on economic growth. Change in gross fixed capital formation had a negative and significant impact on economic growth. However, change in gross fixed capital formation had a positive and insignificant impact on economic growth in the first lag. Change in inflation had a negative and significant impact on economic growth in the shortrun. However, change in inflation had a positive and insignificant relationship with economic growth in the first lag. Change in government final consumption expenditure had a negative and insignificant impact on economic growth contrary to the long-run result. This implies that government final consumption expenditure does not support economic growth in the short-run. In line with the coefficient of $\mathrm{ECM}_{\mathrm{t}-1}, 9.8 \%$ of the previous deviation in economic growth from equilibrium is corrected by it within one year. As expected, the speed of adjustment was negative. However, it was quite slow. 
Table-7. Results of the Granger Causality Test (TY Augmented Lags Methods).

\begin{tabular}{l|c|c}
\hline & \multicolumn{2}{|c}{ Sources of Causation } \\
\hline Dependent/ Variable & LOGRGDPPC & TOPEN \\
& $\chi^{2}$ & - \\
\hline TOPEN & 9.721703 & $113.3579^{*} * *$ \\
\hline LOGRGDPPC & - & Note: ***,** and * indicate significance at the 1 per cent, 5 per cent and 10 per cent respectively.
\end{tabular}

Table 7 confers the results of the Toda and Yamamoto (TY) estimation. The findings showed the presence of unidirectional causality from real GDP per capita growth rate to trade liberalization for Nigeria. This implies that real GDP per capita growth rate promotes trade liberalization in Nigeria. This result corroborates those of Olufemi (2004); Nduka et al. (2013) and Yakubu and Akanegbu (2018) but violates that of Tyopev (2019) and Nwinee and Olulu-Briggs (2016).

\section{CONCLUSION AND RECOMMENDATIONS}

This study explored the short-run and long-run nexus between trade liberalization and economic growth in Nigeria from 1981-2018. Based on the long-run results, trade liberalization, gross fixed capital formation and inflation rate exerted a negative relationship with economic growth. However, general government final consumption expenditure had a positive impact on economic growth. The negative relationship between trade liberalization and economic growth implies that trade liberalization does not support economic growth in Nigeria. However, it exerted a positive impact on economic growth in the first lag under the short-run results. Hence, this study failed to substantiate the genuineness of the extensive trade liberalization campaign through the bright idea of international organizations in the late 1980s and early 1990s. The causality results showed the existence of a unidirectional relationship from real GDP per capita to trade liberalization in Nigeria. The result implies that a specified degree of economic growth may be a precondition for Nigeria to expand its trade and, thus, policies of economic growth are critical to increasing trade. The recommendations stemming from these results are as follows: The Central Bank of Nigeria (CBN) and policymakers of the government should prescribe sound macroeconomic policies that will ensure price stability to reduce the uncertainties associated with an investment in the economy to boost economic growth.

The Central Bank of Nigeria (CBN) should initiate measures for the promotion of investments through access to credit facilities. The government should also provide incentives to investors and a conducive environment for investment. As a matter of urgency, the government should address all impediments to investments in Nigeria. This is because investment was an issue of worry due to its negative impact on economic growth in the short-run and long-run. The negative impact of trade liberalization on economic growth from the standpoint of economic policy indicates that long-run economic growth in Nigeria is hampered by trade liberalization. Thus, policymakers of the government should balance its strategies of trade liberalization as a result of the inability of the economy to absorb the adverse shocks from foreign trade (Moyo \& Khobai, 2018). Thus, appropriate fiscal and monetary policies should be deployed for the protection of the economy against foreign influences. Moreover, the diversification of the structure of export is necessary to ensure that manufactured products are exported more.

Funding: This study received no specific financial support.

Competing Interests: The authors declare that they have no competing interests.

Acknowledgement: All authors contributed equally to the conception and design of the study. 


\section{REFERENCES}

Aboubacar, B., Xu, D., \& Ousseini, A. M. (2014). Does trade openness matter for economic growth in Niger? Theoretical Economics Letters, 4(09), 916-927.

Adhikary, B. K. (2011). FDI, trade openness, capital formation, and economic growth in Bangladesh: A linkage analysis. International Journal of Business and Management, 6(1), 16-28.Available at: https://doi.org/10.5539/ijbm.v6n1p16.

Aditya, A. (2014). Trade liberalization, product variety and growth. Export-Import Bank of India Occasional Paper No. 167.

Ajayi, E. O., \& Araoye, F. E. (2019). Trade openness and economic growth in Nigeria. International Journal of Economics and Financial Management, 4(2), 50-63.

Ali, W., \& Abdullah, A. (2015). The impact of trade openness on the economic growth of Pakistan: 1980-2010. Global Business and Management Research: An International Journal, 7(2), 120-129.

Anyanwu, S. O., Siyan, P., \& Duru, I. U. (2009). Foreign direct investment and economic growth: Empirical evidence from time series data in Nigeria. Journal of Economics and Allied Fields, 4(1), 64-71.

Barro, R. J., \& Sala-i-Martin, X. (1997). Economic growth. New Delhi: McGraw-Hill.

Barro, R. J. (1996). Determinants of economic growth: A cross-country empirical study. Unpublished manuscript. Retrieved from http://search.ebscohost.com.proxy.iwu.edu/login.aspx?direct $=$ true $\& \mathrm{db}=\mathrm{ecn} \& \mathrm{AN}=0718330 \&$ site $=\mathrm{eds}-$ live\&scope=site; $\underline{\text { http://www.nber.org/papers/w5698.pdf. }}$

Bekele, Y. E. (2017). Exploring the relationship between trade liberalization and Ethiopian economic growth. MPRA Paper No. 83584.

Ben-David, D. (1993). Equalizing exchange: Trade liberalization and income convergence. The Quarterly Journal of Economics, 108(3), 653-679.Available at: https://doi.org/10.2307/2118404.

Bibi, S. (2014). Impact of trade openness, FDI, exchange rate and inflation on economic growth: A case study of Pakistan. International Journal of Accounting and Financial Reporting, 4(2), 236-257.

Bittencourt, M. V. L. (2004). The impacts of trade liberalization and macroeconomic instability on the Brazilian economy. An Unpublished Doctor of Philosophy Degree of Ohio State University.

Chartas, V. (2012). The impact offoreign direct investment on economic growth in China. An Unpublished M.Sc Thesis of the Erasmus School of Economics, Erasmus University Rotterdam.

Chile, L. M., \& Talukder, D. (2013). The paradox of agricultural trade liberalization in Bangladesh and Tanzania. American Journal of Trade and Policy, 1(1), 23-31.Available at: https://doi.org/10.18034/ajtp.v1i1.358.

Constant, N. B. (2010). The relationship between foreign direct investment, trade openness and growth in Cote d'Ivoire. International Journal of Business and Management, 5(7), 99-107.

Dabel, I. (2016). Trade openness and economic growth: Evidence from Ghana. An Unpublished Master of Philosophy Degree in Economics of the University of Cape Coast.

Dao, A. T. (2014). Trade openness and economic growth. Mark A. Israel '91 endowed summer research fund in economics. Retrieved from http://digitalcommons.iwu.edu/israel_economics/2.

Das, D. K. (2002). Trade liberalization and industrial productivity: An assessment of developing country experiences. Indian Council for Research on International Economic Relations Working Paper No. 77.

Dollar, D., \& Kraay, A. (2003). Institutions, trade and growth. Journal of Monetary Economics, 50(1), 133-162.

Dollar, D. (1992). Outward-oriented developing economies really do grow more rapidly: Evidence from 95 LDCs, $1976-1985$. Economic Development and Cultural Change, 4O(3), 523-544.Available at: https://doi.org/10.1086/451959.

Dufrenot, G., Mignon, V., \& Tsangarides, C. (2010). The trade-growth nexus in the developing countries: A quantile regression approach. Review of World Economics, 146(4), 731-761.Available at: https://doi.org/10.1007/s 10290-010-0067-5.

Duru, I. U., \& Ehidiamhen, P. O. (2018). Empirical investigation of the impact of export diversification on economic growth: Evidence from Nigeria, 1980-2016. Journal of Economics, Management and Trade, 21(7), 1-24.Available at: https://doi.org/10.9734/jemt/2018/42806. 
Echekoba, F. N., Okonkwo, V. I., \& Adigwe, P. K. (2012). Trade liberalization and economic growth: The Nigerian experience (1971-2012). Journal of Poverty, Investment and Development, 14(5), 20-35.

Edwards, S. (1992). Trade orientation, distortions and growth in developing countries. Journal of Development Economics, 39(1), 31-57.

Edwards, S. (1998). Openness, productivity and growth: What do we really know? The Economic Journal, 108(447), 383-398.

Elijah, S., \& Musa, A. B. (2019). Dynamic impact of trade openness on the economic growth in Nigeria. International Journal of Engineering and Advanced Technology, 8(5C), 609-616.

Falvey, R., Foster, N., \& Greenaway, D. (2012). Trade liberalization, economic crises, and growth. World Development, 40(11), $2177-2193$.

Food and Agriculture Organization. (2005). The state of food and agriculture, agricultural trade and poverty: Can trade work for the poor? Rome: Food and Agriculture Organization of the United Nations.

Frankel, J. A., \& Romer, D. H. (1999). Does trade cause growth? American Economic Revier, 89(3), 379-399.

Greenaway, D., Morgan, C., \& Wright, P. (2002). Trade liberalisation and growth: New methods, new evidence. Journal of Development Economics, 67(1), 229-244.

Grosman, G., \& Helpman, E. (1991). Innovation and growth in the global economy. Cambridge: MIT Press.

Harrison, A. (1996). Openness and growth: A time-series, cross-country analysis for developing countries. Journal of Development Economics, 48(2), 419-447.Available at: https://doi.org/10.1016/0304-3878(95)00042-9.

Hart, O. (1983). The market mechanism as an incentive scheme. Bell Journal of Economics, 14(2), 366-382.Available at: https://doi.org/10.2307/3003639.

Howitt, P. (1998). Endogenous growth. Retrieved from www.econ.brown.edu. [Accessed 19th November 2018].

Kalu, E. U., Nwude, C. E., \& Nnenna, N. (2016). Does trade openness engineer economic growth in Nigeria? (Empirical evidence covering 1991 to 2013). Global Journal of Management and Business Research, 16(4), 1-8.

Kebede, E. (2002). Trade liberalisation, openness and economic growth in less-developed countries. An Unpublished Doctor of Philosophy Degree of the Business School of Middlesex University.

Keho, Y. (2017). The impact of trade openness on economic growth: The case of Cote d'Ivoire. Cogent Economics $\S^{2}$ Finance, 5(1), 1-14.Available at: http://dx.doi.org/10.1080/23322039.2017.1332820.

Kneller, R., Morgan, C. W., \& Kanchanahatakij, S. (2008). Trade liberalisation and economic growth. World Economy, 31(6), 701719.

Krueger, A. O. (1997). Trade policy and economic development: How we learn. American Economic Review, 87(1), 1-22.

Krugman, P. R. (1990). Rethinking international trade. Cambridge, Massachusetts: MIT Press.

Krugman, P. (1987). The narrow moving band, the Dutch disease, and the competitive consequences of Mrs Thatcher: Notes on trade in the presence of dynamic scale economies. Journal of Development Economics, 27(1-2), 41-55.Available at: https://doi.org/10.1016/0304-3878(87)90005-8.

Levine, R., \& Renelt, D. (1992). A sensitivity analysis of cross-country regressions. American economic revierw, 82(4), 942-963.

Lucas, J. R. E. (1988). On the mechanics of economic development. Journal of Monetary Economics, 22(1), 3-42.

Mangir, F., Acet, H., \& Baoua, M. M. A. (2017). An empirical analysis of the relationship between trade openness and economic growth in Niger. Paper presented at the Econ World 2017@Paris Proceedings, July 25-27, 2017; Paris, France.

Manwa, F. (2015). Impact of trade liberalisation on economic growth: The case of the Southern African Customs Union (SACU) countries. PhD Thesis, Southern Cross University, Lismore, NSW.

Mercan, M., Gocer, I., Bulut, S., \& Dam, M. (2013). Equalizing exchange: Trade liberalization and income convergence. Eurasian Journal of Business and Economics, 6(11), 1-14.

Michaely, M., Choksi, A. M., \& Papageorgiou, D. (1991). Liberalizing foreign trade: Lessons of experience in the developing world, a research project of the World Bank (Vol. 7). Cambridge, MA: Basil Blackwell.

Moyo, C., \& Khobai, H. (2018). Trade openness and economic growth in SADC countries. MPRA Paper No. 84254. 
Moyo, C., Nwabisa, K., \& Hlalefang, K. (2017). The relationship between trade openness and economic growth: The case of Ghana and Nigeria. MPRA Paper No. 81317.

Musila, J. W., \& Yiheyis, Z. (2015). The impact of trade openness on growth: The case of Kenya. Journal of Policy Modeling, 37(2), 342-354.Available at: https://doi.org/10.1016/j.jpolmod.2014.12.001.

Narayan, P. K. (2004). Reformulating critical values for the bounds F-statistics approach to cointegration: An application to the tourism demand model for Fiji. Department of Economics Discussion Papers, Working Paper No. 02/04.

Nduka, E. K. (2013). Openness and economic growth in Nigeria. Journal of Education and Practice, 4(1), 68-73.

Nduka, E. K., Chukwu, J. O., Ugbor, K. I., \& Nwakaire, O. N. (2013). Trade openness and economic growth: A comparative analysis of the pre and post-structural adjustment programme (SAP) periods in Nigeria. Asian Journal of Business and Economics, 3(3.4), 1-12.

Newfarmer, R., \& Sztajerowska, M. (2012). Trade and employment in a fast-changing world. In D. Lippokit (Ed.), Policy priorities for international trade and jobs (pp. 7-73). Paris: OECD Publishing.

North, D. (1990). Institutions, institutional change and economic performance. New York: Cambridge University Press.

Nwinee, B. F., \& Olulu-Briggs, O. V. (2016). Trade openness, financial development, and the Nigerian economy. American International Journal of Contemporary Research, 6(3), 170-183.

Olasode, S. O., Raji, O., Adedoyin, O. A., \& Ademola, I. A. (2015). Trade openness and economic growth: A reflection from Nigeria (1981-2012). International Journal of Economics, Commerce and Management, 3(5), 813-820.

Olufemi, S. M. (2004). Trade openness and economic growth in Nigeria: Further evidence on the causality issue. South African Journal of Economic and Management Sciences, 7(2), 299-315.Available at: https://doi.org/10.4102/sajems.v7i2.1375.

Pesaran, M. H., \& Shin, Y. (1999). An autoregressive distributed lag modelling approach to cointegration analysis. econometrics and economic theory in the 20th century: The Ragnar Frisch Centennial Symposium. Cambridge: Cambridge University Press.

Pesaran, M. H., Shin, Y., \& Smith, R. J. (2001). Bounds testing approaches to the analysis of level relationships. Journal of Applied Econometrics, $16(3), 289-326$. Available at: https://doi.org/10.1002/jae.616.

Qazi, M. A. H. (2015). Impact of economic liberalization on economic growth in the case of Pakistan. An Unpublished Doctor of Philosophy Degree of the Faculty of Economics and Administration, University of Malaya, Kuala Lumpur, Malaysia.

Ramzan, D., \& Kiani, A. K. (2012). Analyzing the relationship between FDI, trade openness and real output growth: An ECM application for Pakistan. International Journal of Basic and Applied Science, 1(2), 440-447.

Read, D. M., \& Parton, K. A. (2009). Economic deregulation and trade liberalization in Kenya, Tanzania and Uganda: Growth and poverty. Journal of Economic Issues, 43(3), 567-586.Available at: https://doi.org/10.2753/jeio021-3624430301.

Rigobon, R., \& Rodrik, D. (2005). Rule of law, democracy, openness, and income: Estimating the interrelationships 1. Economics of Transition, 13(3), 533-564.Available at: https://doi.org/10.1111/j.1468-0351.2005.00226.x.

Rodriguez, F., \& Rodrik, D. (2001). Trade policy and economic growth: A sceptic's guide to the cross-national evidence. In B. Bernanke and K. Rogoff(Eds.), NBER Macroeconomics Annual. Cambridge, MA: MIT Press.

Rodrik, D. (2006). Goodbye Washington consensus, hello Washington confusion? A review of the World Bank's economic growth in the 1990s: Learning from a decade of reform. Journal of Economic Literature, 44(4), 973-987.Available at: https://doi.org/10.1257/jel.44.4.973.

Rodrik, D., Subramanian, A., \& Trebbi, F. (2002). Institutions rule: The primacy of institutions over geography and integration in economic development. National Bureau of Economic Research Working Paper Series No. 9305.

Romer, P. M. (1990). Are nonconvexities important for understanding growth? The American Economic Review, 80(2), 97-103.

Romer, P. M. (1986). Increasing returns and long-run growth. Journal of Political Economy, 94(5), 1002-1037.Available at: https://doi.org/10.1086/261420.

Sachs, J. D., \& Warner, A. (1995). Economic reform and the process of global integration. Brookings Papers on Economic Activity, 1995(1), 1-1 18.Available at: https://doi.org/10.2307/2534573.

Sakyi, D. (2011). Trade openness, foreign aid and economic growth in post-liberalisation Ghana: An application of ARDL bounds test. Journal of Economics and International Finance, 3(3), 146-156. 
Sala-i-Martin, X. X. (1997). I just run two million regressions. American Economic Review, 87(2), $178-183$.

Salvatore, D., \& Hatcher, T. (1991). Inward oriented and outward oriented trade strategies. The Journal of Development Studies, 27(3), 7-25.Available at: https://doi.org/10.1080/00220389108422201.

Salvatore, D. (2007). International economics (9th ed.). USA: John Wiley and Sons Inc.

Savvides, A. (1995). Economic growth in Africa. World Development, 23(3), 449-458.

Thindwa, M. O., \& Seshamani, V. (2014). Trade liberalization and the performance of the tobacco sector in Malawi. Journal of Emerging Issues in Economics, Finance and Banking, 3(1), 962-975.

Tyopev, I. (2019). Trade openness and economic growth in selected West African countries. An Unpublished PhD Economics thesis of Benue State University, Makurdi, Benue State, Nigeria.

Vamvakidis, A. (2002). How robust is the growth-openness connection? Historical evidence. Journal of Economic Growth, 7(1), 5780 .

Vamvakidis., A. (1999). Regional trade agreements or broad liberalization: Which path leads to faster growth? IMF Staff Papers, $46(1), 42-68$.

Wang, Y., \& Yao, Y. (2003). Sources of china's economic growth 1952-1999: Incorporating human capital accumulation. China Economic Review, 14(1), 32-52.Available at: https://doi.org/10.1016/s1043-951x(02)00084-6.

Winters, L. A. (2004). Trade liberalisation and economic performance: An overview. The Economic Journal, 114(493), F4F2 1.Available at: https://doi.org/10.1111/j.0013-0133.2004.00185.x.

World Bank World Development Indicators. (2020). Data on real gross domestic product per capita growth rate: World Bank, World Development Indicators.

Yakubu, M. M., \& Akanegbu, B. N. (2018). Trade openness and economic growth: Evidence from Nigeria. European Journal of Business, Economics and Accountancy, 6(4), 30-44.

\section{APPENDICES}

Appendix 1

\section{Data Set}

Table-7. Data used for the study.

\begin{tabular}{|c|c|c|c|c|c|}
\hline Year & RGDPPC & TOPEN & GFCF & INFL & GOVFCEXP \\
\hline 1981 & 1741.715028 & 18.17172618 & 89.38612615 & 20.81282291 & 1.776405725 \\
\hline 1982 & 1581.562266 & 13.77983316 & 85.94140115 & 7.697747247 & 2.106434616 \\
\hline 1983 & 1373.537169 & 10.04496861 & 75.75651206 & 23.21233155 & 2.077116614 \\
\hline 1984 & 1324.296747 & 9.380541231 & 58.95628791 & 17.82053329 & 2.091335722 \\
\hline 1985 & 1367.118747 & 10.39197861 & 46.39544698 & 7.435344828 & 1.939839163 \\
\hline 1986 & 1332.804867 & 9.135845723 & 54.94827038 & 5.717151454 & 1.929235512 \\
\hline 1987 & 1339.813403 & 19.49533511 & 50.04988787 & 11.29032258 & 1.632708798 \\
\hline 1988 & 1400.734024 & 16.94060969 & 43.75477314 & 54.51122478 & 1.55269831 \\
\hline 1989 & 1390.804949 & 34.18261725 & 52.48744487 & 50.46668812 & 1.315222341 \\
\hline 1990 & 1515.013257 & 30.92474008 & 53.12219353 & 7.364400306 & 1.220140672 \\
\hline 1991 & 1482.221263 & 37.02160486 & 48.40018216 & 13.0069731 & 1.220981836 \\
\hline 1992 & 1512.248435 & 38.22738831 & 43.77439439 & 44.58884272 & 2.047628602 \\
\hline 1993 & 1444.846342 & 33.71975493 & 44.47636408 & 57.16525283 & 2.148452483 \\
\hline 1994 & 1383.688661 & 23.05923645 & 42.06783621 & 57.03170891 & 1.769021019 \\
\hline 1995 & 1348.680651 & 39.52837841 & 37.20593267 & 72.8355023 & 1.166196047 \\
\hline 1996 & 1370.72593 & 40.25772925 & 36.58167005 & 29.26829268 & 0.911234589 \\
\hline 1997 & 1376.302499 & 51.46101079 & 38.42226127 & 8.529874214 & 0.912570547 \\
\hline 1998 & 1377.08974 & 39.27860747 & 40.55340148 & 9.996378124 & 1.375668403 \\
\hline 1999 & 1350.983834 & 4.45 & 38.2780 & 6.618373395 & 1.383378314 \\
\hline 2000 & 1383.666051 & 48.99559947 & 34.04928497 & 6.933292156 & 2.123442198 \\
\hline 2001 & 1429.196527 & 49.68050029 & 30.03794342 & 18.87364621 & 1.990621474 \\
\hline 2002 & 1607.238267 & 40.03516859 & 26.76865607 & 12.8765792 & 1.340487984 \\
\hline 2003 & 1682.099989 & .33496486 & 8.37089582 & 14.03178 & 0.951746573 \\
\hline 2004 & 1791.261545 & 31.89587044 & 26.06325442 & 14.99803382 & 4.787637352 \\
\hline 2005 & 1857.925564 & 33.05946007 & 24.96612489 & 17.86349337 & 4.54454697 \\
\hline 2006 & 1919.724203 & 42.5665658 & 26.1664999 & 8.22522152 & 5.125841682 \\
\hline 2007 & 1993.097411 & 39.33693151 & 20.18003679 & 5.388007969 & 9.448340036 \\
\hline 2008 & 2072.273486 & 40.79683535 & 18.85976721 & 11.58107517 & 9.428957363 \\
\hline 2009 & 2179.989416 & 36.05871041 & 21.11545461 & 12.55496039 & 8.649947944 \\
\hline 2010 & 2292.445156 & 43.32075684 & 16.81501324 & 13.72020184 & 8.848100208 \\
\hline 2011 & 2350.336824 & 53.27795833 & 15.67631067 & 10.84002754 & 8.572152255 \\
\hline 2012 & 2384.954171 & 44.53236805 & 14.21112008 & 12.21778174 & 8.228177843 \\
\hline 2013 & 2476.863878 & 31.04885996 & 14.16872621 & 8.475827285 & 7.15521853 \\
\hline 2014 & 2563.899969 & 30.885193 & 15.08353336 & 8.062485824 & 6.464486129 \\
\hline 2015 & 2563.148864 & 21.33265187 & 14.82717543 & 9.009387183 & 935159057 \\
\hline 2016 & 245 & 20.722518 & 22 & & 5.3842817 \\
\hline 2017 & 2412.367125 & 26347599 & 564 & 16.52353998 & 4.403315163 \\
\hline 2018 & 2395 & 0783349 & 19.01838355 & 12.09473155 & 5.60432 \\
\hline
\end{tabular}

Source: World Development Indicators - World Bank DataBank. 


\section{Appendix 2}

Graph of Diagnostic Tests

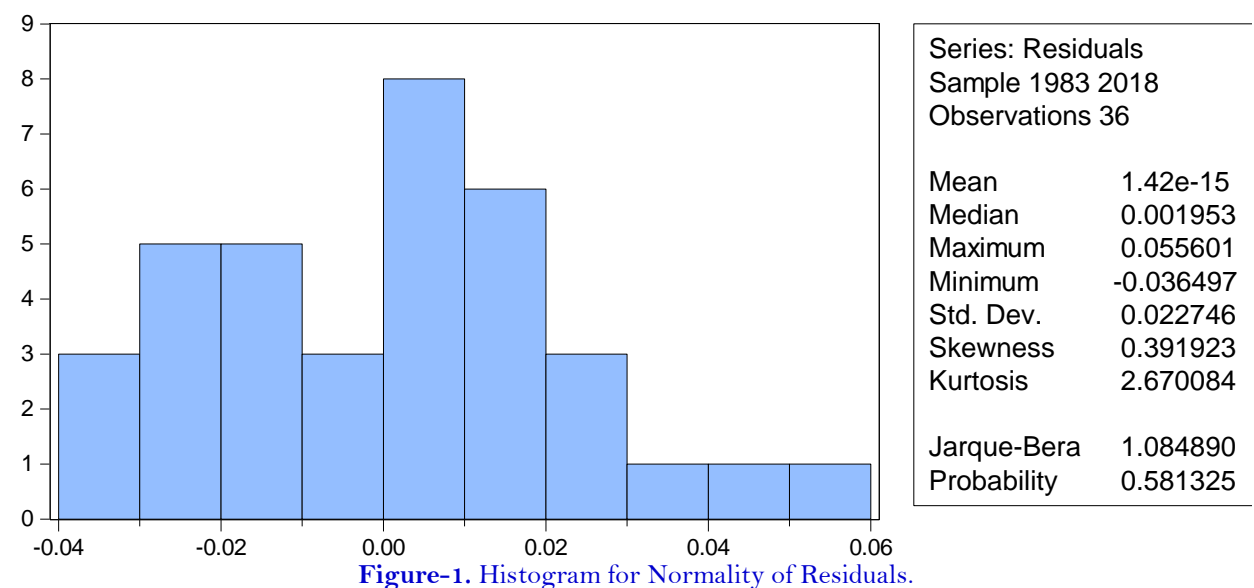

Source: Ex tract from E-views econometric software.

Views and opinions expressed in this article are the views and opinions of the author(s), Asian Development Policy Review shall not be responsible or answerable for any loss, damage or liability etc. caused in relation to/arising out of the use of the content. 